\title{
PERANCANGAN MEDIA KAMPANYE KESELAMATAN LALU LINTAS SEJAK DINI MELALUI PROGRAM TRANSPORTASI SEHAT MERAKYAT
}

\author{
Hergy Andriawan ${ }^{1)}$ Sophia Purbasari ${ }^{2)}$ Citra Kemala Putri ${ }^{3)}$ \\ ${ }^{1,2,3}$ Fakultas Komunikasi dan Desain, Universitas Informatika dan Bisnis Indonesia \\ Email: hergyyy391@gmail.com ${ }^{1}$ sophia041@unibi.ac.id ${ }^{2}$ citrakemala@unibi.ac.id ${ }^{3}$
}

\begin{abstract}
ABSTRAK
Kampanye keselamatan lalu lintas sejak dini melalui transportasi sehat merakyat ini adalah program pemerintah yang diamanatkan didalam Pasal 203 UU no 22 Tahun 2009 tentang lalu lintas dan angkutan jalan, bertujuan untuk mengurangi kepadatan arus lalu lintas, meminimimalisir angka kecelakaan pada usia remaja ataupun sejak dini, dan mengurangi polusi udara yang diakibatkan oleh kendaraan bermotor melalui transportasi sehat merakyat, diantaranya yaitu Bike to School, Walk to School, Bike to Work, dan Walk to Work. Kampanye tersebut dilaksanakan berdasarkan kepada data kepolisian yang menyatakan bahwa pelajar usia sekolah menjadi penyumbang angka terbesar kecelakaan dan kepadatan lalu lintas di Kota Cimahi. Tujuan perancangan ini yaitu merancang media kampanye keselamatan lalu lintas sejak dini melalui trasnportasi sehat merakyat yang efektif dan efisien. Perancangan ini dalam pengumpulan data menggunakan metode penelitian Mix Method, yaitu melakukan wawancara kepada Kanit Dikyasa Satlantas Polres Cimahi dan siswa SMAN 1 Cimahi, juga melakukan pembagian kuesioner kepada siswa SMAN 1 Cimahi. Hasil dari perancangan ini dapat diketahui bahwa Program kampanye tersebut belum maksimal dilaksanakan, baik secara media maupu teknis pelaksanaan, sehingga belum efektif dalam mereduksi angka tingkat kepadatan dan kecelakaan lalu lintas oleh pelajar di Kota Cimahi.
\end{abstract}

Kata Kunci: Kampanye, Keselamatan lalu lintas sejak dini, Transportasi Sehat Merakyat

\begin{abstract}
Early traffic safety campaigns through populist healthy transportation is a government program mandated in Article 203 of Law 22/2009 concerning traffic and road transportation, aimed at reducing the density of traffic flow, minimizing accident rates in adolescents or since early, and reduce air pollution caused by motorized vehicles through populist healthy transportation, including Bikes to School, Walk to School, Bike to Work, and Walk to Work. The campaign was carried out based on police data which stated that school-age students accounted for the largest number of accidents and traffic congestion in Cimahi City. Objectiveity this campaign is to design a traffic safety campaign media early on through effective and efficient public transportation. The design of this data collection was using the Mix Method research method, which was conducting interviews with the Headquarters of the Cimahi Police Satlasa Task Force and Cimahi SMAN 1 students, also distributing questionnaires to Cimahi 1 High School students. The campaign program has not been maximally implemented, both in media and technical implementation, so that it has not been effective in reducing the level of traffic density and traffic accidents by students in Cimahi City.
\end{abstract}

Keywords: Campaign, Traffic safety early on, People's Healthy Transportation 


\section{PENDAHULUAN}

Program kampanye keselamatan berkendara sejak dini melalui transportasi sehat merakyat ini adalah bagian dari program nasional yang sebagaimana diamanatkan didalam Pasal 203 UU no 22 Tahun 2009 tentang lalu lintas dan angkutan jalan, program ini merupakan salah satu program yang diamanatkan oleh pemerintah bertujuan untuk mengurangi kepadatan arus lalu lintas, meminimimalisir angka kecelakaan pada usia remaja ataupun sejak dini, dan mengurangi polusi udara yang diakibatkan oleh kendaraan bermotor, yaitu melalui kegiatan Bike to School, Walk to School, Bike to Work, dan Walk to Work, dengan demikian dinamakan sebagai transportasi sehat merakyat. Berdasarkan hasil wawancara yang dilakukan kepada Kepala Unit Pendidikan dan Rekayasa Lalu lintas Satuan Lalu lintas Kepolisian Resor Cimahi Inspektur Polisi Dua Deden Indrajaya, S.H, beliau menyatakan bahwa fenomena yang mendasari program kampanye ini yaitu kebiasaan yang salah dari orang tua siswa, baik siswa SMA, SMP, bahkan SD dengan alasan jarak rumah ke sekolah yang dekat, dan orang tua yang enggan mengantar anaknya ke sekolah memfasilitasi dengan memberikan kendaraan roda dua. Hal ini adalah bentuk kasih sayang yang salah dari orang tua, karena amanat undang-undang ini agar siswa-siswa yang masih dibawah umur tidak menjadi salah satu penyumbang angka kepadatan lalu lintas dan angka kecelakaan, khususnya di Kota Cimahi.

Melihat fenomena yang terjadi di lapangan, Satlantas Polres Cimahi melaksanakan program kampanye keselamatan lalu lintas sejak dini melalui transportasi sehat merakyat ini turun langsung ke semua sekolah-sekolah yang ada

1 Hilman Kamaludin. 2018. "Pengendara Motor Usia Remaja Penyumbang Kecelakaan Terbanyak di Wilkum Polres Cimahi”. < http://jabar.tribunnews.com/2018/07/23/pengendaramotor-usia-remaja-penyumbang-kecelakaanterbanyak-di-wilkum-polres-cimahi>. Diakses pada tanggal 9 November 2018, 09.45 WIB di Kota Cimahi, baik itu dari Taman Kanakkanak, Sekolah Dasar, Sekolah Menengah Pertama, dan Sekolah Menengah Atas, dengan tujuan memberikan edukasi, sosialisasi, dan wawasan mengenai keselamatan lalu lintas dan transportasi sehat merakyat. Hal ini karena pihak Satlantas Polres Cimahi sudah melakukan diseminasi yang diprakarsai oleh Menteri Pendidikan, artinya pendidikan lalu lintas ini sudah masuk ke tingkat sekolah dan untuk kemudian dijalankan oleh Dinas Pendidikan (Disdik) didaerah masing-masing, karena dari Kementrian Pendidikan pun mengharuskan pendidikan lalu lintas ini masuk ke kurikulum sekolah, yaitu pada mata pelajaran Pendidikan Kewarganegaraan (PKn).

Kepala Bagian Operasi (KBO), Satuan Lalu lintas (Satlantas) Polres Cimahi IPTU Duddy Iskandar kepada TribunJabar (23/7), bahwa pengendara motor usia 15 tahun hingga 20 tahun atau usia pelajar menjadi penyumbang angka kecelakaan yang cukup tinggi di wilayah hukum Polres Cimahi, beberapa faktor penyebabnya yaitu secara mental usia pelajar itu belum matang, tingkat emosionalnya masih labil dan sulit dikontrol, dan tingkat kewaspadaan saat berkendaranya pun masih kurang. Hal itu dibuktikan dari mereka yang belum bisa memiliki SIM, karena persyaratannya minimal harus 17 tahun, untuk itu secara aturan, siswa sekolah terutama SMP yang membawa motor itu merupakan suatu bentuk pelanggaran. ${ }^{1}$

Kepala Dinas Pendidikan Kota Cimahi, Dikdik Suratno Nugrahawan juga ikut menyikapi fenomena ini saat ditemui oleh redaksi TribunJabar (23/7), Beliau menyampaikan bahwa pelajar yang belum cukup umur mengendarai kendaraan itu mudah terpancing ketika berkendara, dan sangat membahayakan pengendara lain. ${ }^{2}$

${ }^{2}$ Hilman Kamaludin. 2018. "Kadisdik Kota Cimahi Minta Polisi Tindak Tegas Pelajar yang Membawa Motor". <http://jabar.tribunnews.com/2018/07/23/kadisdikkota-cimahi-minta-polisi-tindak-tegas-pelajar-yangmembawa-motor $>$. Diakses pada tanggal 9 November 2018, 10.30 WIB 
Berdasarkan hasil wawancara yang dilakukan kepada beberapa sekolah, pihak sekolah sendiri sudah dengan tegas membuat dan menetapkan peraturan bahwa siswa tidak boleh membawa kendaraan bermotor ke sekolah, namun pihak sekolah mengetahui bahwa masih ada siswa yang tidak menghiraukan aturan tersebut dan membawa motor ke sekolah dengan memarkirkan motornya di tempat yang tidak jauh dari sekolah.

\section{KAJIAN PUSTAKA}

"Perancangan adalah Suatu desain atau rancangan/anggitan banyak dipahami oleh banyak pihak sebagai suatu kegiatan yang patuh terhadap prinsip, metoda, tata urut perlakuan atau hierarki yang ketat aturan." (Toekio, 2007 : 113).

$$
\text { "Rogers dan Storey (1987) }
$$

mendefinisikan kampanye sebagai serangkaian tindakan komunikasi yang terencana dengan tujuan untuk menciptakan efek tertentu pada sejumlah besar khalayak yang dilakukan secara berkelanjutan pada kurun waktu tertentu." (Venus, 2004:7).

"Kampanye sosial adalah upaya membesar-besarkan untuk memberikan komunikasi, ide-ide dan praktek melalui media masa dan komunikasi interpersonal." (Yuwono, 2016:13).

"Kampanye keselamatan lalu lintas sejak dini melalui transportasi sehat merakyat adalah program kampanye di amanatkan oleh pemerintah bertujuan untuk mengurangi kepadatan arus lalu lintas, meminimimalisir angka kecelakaan pada usia remaja ataupun sejak dini, dan mengurangi polusi udara yang diakibatkan oleh kendaraan bermotor, yaitu melalui kegiatan transportasi sehat merakyat. Transportasi sehat merakyat tersebut diantaranya adalah Bike to School, Walk to School, Bike to Work, dan Walk to Work.

\footnotetext{
${ }^{3}$ Ivony. "35 Pengertian Komunikasi Menurut Para Ahli”. Melalui

<https://pakarkomunikasi.com/pengertian-
}

Program kampanye keselamatan berkendara sejak dini melalui transportasi sehat merakyat ini merupakan program nasional yang di amanatkan didalam Pasal 203 UU no 22 Tahun 2009 tentang lalu lintas dan angkutan jalan".

"Booklet adalah buku berukuran kecil (setengah kuarto) dan tipis, tidak lebih dari 30 lembar bolak balik yang berisi tentang tulisan dan gambar-gambar. Istilah booklet berasal dari buku dan leaflet artinya media booklet merupakan perpaduan antara leaflet dan buku dengan format (ukuran) yang kecil seperti leaflet." (Simamora, 2009:17).

"Pengertian poster adalah suatu media visual dua dimensi berisikan gambar dan pesan tertulis yang singkat untuk menyampaikan pesan-pesan tertentu, serta mampu mempenggaruhi dan memotivasi tingkah laku orang yang melihatnya." (Arsyad, 2007).

Menurut Achmad S. Ruky, komunikasi merupakan proses pemindahan dan pertukaran pesan, dimana pesan ini dapat berbentuk fakta, gagasan, perasaan, data atau informasi dari seseorang kepada orang lain. Proses ini dilakukan dengan tujuan untuk mempengaruhi dan/ atau mengubah informasi yang dimiliki serta tingkah laku orang yang menerima pesan tersebut. ${ }^{3}$

Menurut

Michael

Kroeger, bahwa Visual Communication (komunikasi visual) merupakan latihan teori dan konsep-konsep. Konsep tersebut dihasilkan melalui tema-tema visual dengan menggunakan warna, bentuk, garis dan penjajaran (juxtaposition). Sedangkan Desain Komunikasi Visual menurut Suyanto diartikan sebagai sebuah seni serta komunikasi yang digunakan kebutuhan bisnis dan industri. Ketrampilan ini bisa meliputi periklanan dan penjualan produk, menciptakan identitas visual untuk institusi, produk dan perusahaan. Serta lingkungan grafis, desain informasi, dan secara visual melengkapi pesan dalam publikasi. ${ }^{4}$

\footnotetext{
komunikasi-menurut-para-ahli>. Ivony. Diakses pada 19 April 2019, 16.05

${ }^{4}$ Heru. 2017 "Desain Komunikasi Visual -

Pengertian, Ruang Lingkup, dan Jenisnya”. Melalui
} 
Menurut Archer, Desain adalah berupa bentuk suatu kebutuan badani dan juga rohani manusia yang di utarakan lewat berbagai pengalaman, keahlian dan pengetahuannya tersebut mencerminkan perhatian terhadap apresiasi dan juga adaptasi terhadap sekitar, khususnya yang masih ada hubungannya dengan bentuk, komposisi, arti, nilai, dan berbagai tujuan benda buatan manusia ${ }^{5}$.

Menurut Rohidi, gambar ilustrsi berkaitan dengan seni rupa merupakan pengamaran melalui suatu elemen rupa agar lebih menerangkan, memerindah atau menjelaskan sebuah teks, agar pembacanya bisa ikut merasakan secara langsung melalui mata sendiri, sifat-sifat gerak, dan kesan dari cerita yang disajikan. ${ }^{6}$

"Menurut Roy Brewer (1971) dalam buku "Pengantar Tipografi":

"Tipografi dapat memiliki arti luas, yang meliputi penataan dan pola halaman, atau cetakan atau dalam arti yang lebih sempit hanya mencakup pemilihan, pengaturan, dan berbagai hal yang berkaitan dengan pengaturan jalur pengaturan huruf (set), tidak termasuk ilustrasi dan elemen lainnya, bukan surat di halaman dicetak." (Sudiana, 2001: 2). ${ }^{7}$

AISAS adalah model yang dirancang untuk melakukan pendekatan secara efektif kepada target audiens dengan melihat perubahan perilaku yang terjadi khususnya terkait dengan latar belakang kemajuan teknologi internet." (Sugiyama, Andree, 2011:79)

\section{METODE PENELITIAN}

Pada perancangan ini peneliti dalam membuat karya menggunakan metode riset atau penelitian dengan metodologi Mixed method. "Mix method adalah metode

\footnotetext{
<https://pakarkomunikasi.com/komunikasi-visual>. Diakses pada 19 April 2019, 16.25

${ }^{5}$ Ruangguru.co.id. 2018. "13 Definisi desain menurut para ahli". Melalui

$<$ https://www.ruangguru.co.id/pengertian-desainmenurut-para-ahli/> Diakses pada 19 April 2019

${ }^{6}$ Kurniawan, Aris 2019. "Pengertian Ilustrasi menurut Para Ahli beserta Sejarah, Fungsi, dan Tujuannya” Melalui
}

penelitian dengan mengkombinasikan antara dua metode penelitian sekaligus, kualitatif dan kuantitatif dalam suatu kegiatan penelitian, sehingga akan diperoleh data yang lebih komprehensif, valid, reliabel, dan objektif." (Sugiyono, 2011:18).

\section{Teknik Pengumpulan Data Studi Pustaka}

Studi pustaka dengan mengumpulkan berbagai macam bahan referensi, seperti jurnal penelitian, tesis, disertasi, buku-buku teori dan sumbersumber lain termasuk informasi yang diperoleh dari internet sebagai sumber data.

\section{Kuesioner}

Penelitian dilakukan
dengan membagikan kuesioner wawancara kepada siswa SMAN 1 Cimahi untuk mendapatkan informasi yang terkait dalam suatu penelitian.

\section{Wawancara}

Penelitian dilakukan dengan mewawancarai Kanit Dikyasa Satlantas Polres Cimahi untuk medapatkan informasi yang terkait dalam suatu penelitian.

\section{HASIL DAN PEMBAHASAN}

\section{Kampanye Keselamatan Lalu Lintas} Sejak Dini Melalui Transportasi Sehat Merakyat

Program ini diamanatkan oleh pemerintah bertujuan untuk mengurangi kepadatan arus lalu lintas, meminimimalisir angka kecelakaan pada usia remaja ataupun sejak dini, dan mengurangi polusi udara yang diakibatkan oleh kendaraan bermotor melalui kegiatan transportasi sehat merakyat. Transportasi sehat merakyat tersebut diantaranya yaitu 
Bike to School, Walk to School, Bike to Work, dan Walk to Work.

Program kampanye keselamatan berkendara sejak dini melalui transportasi sehat merakyat ini adalah program nasional yang diamanatkan di dalam Pasal 203 UU no 22 Tahun 2009 tentang lalu lintas dan angkutan jalan.

\section{Fenomena}

Berdasarkan hasil wawancara yang dilakukan kepada Kanit Dikyasa Satuan Lalulintas (Satlantas) Polres Cimahi IPDA Deden Indrajaya, S.H, beliau menyatakan bahwa fenomena yang mendasari program kampanye ini yaitu kebiasaan yang salah dari orang tua siswa, baik siswa SMA, SMP, bahkan SD dengan alasan jarak rumah ke sekolah yang dekat, dan orang tua yang enggan mengantar anaknya ke sekolah memfasilitasi dengan memberikan kendaraan roda dua. Hal ini adalah bentuk kasih sayang yang salah dari orang tua, karena undang-undang ini ditujukan agar para pelajar yang masih dibawah umur tidak menjadi salah satu penyumbang angka kepadatan lalulintas dan angka kecelakaan, khususnya di Kota Cimahi.

\section{Daerah Titik Kepadatan}

Kanit Dikyasa Satlantas Polres Cimahi IPDA Deden Indrajaya, S.H juga menambahkan bahwa

eberapa daerah yang menjadi titik terjadinya kepadatan lalulintas atau dalam bahasa kepolisian biasa disebut Trouble Spot juga berada di sekitar sekolah-sekolah di Kota Cimahi dan terjadi pada jam pagi dan jam sore atau saat jam masuk sekolah atau kantor lalu saat jam pulang sekolah atau kantor, diantaranya yaitu:

1) Pertigaan Kerkof sampai ke Bundaran Leuwigajah, yang berada tidak jauh dari SMKN 1 Cimahi dan SMPN 9 Cimahi.

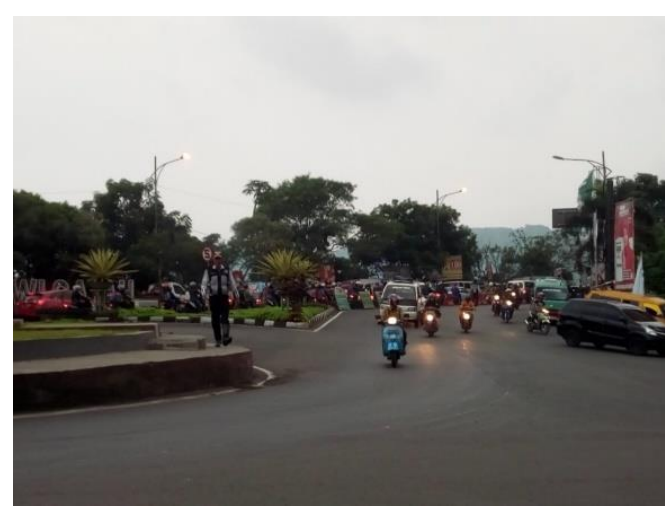

Gambar 1. Bundaran Leuwigajah, Cimahi. Sumber: Dokumentas Pribadi, 2019.

2) Pertigaan Pemkot - Djati, yang menjadi jalur utama untuk menuju ke Kantor Pemerintahan Kota Cimahi, SMPN 10 Cimahi, dan SMAN 3 Cimahi sehingga diberlakukan rekayasa lalulintas setiap pukul $06.00-08.00$ dan pukul $16.00-$ 17.00

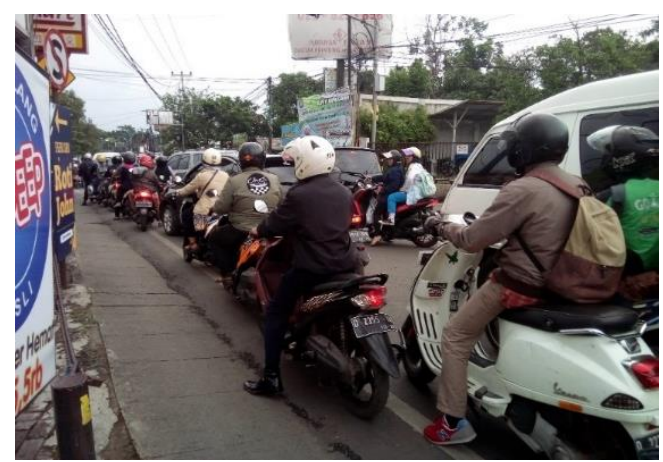

Gambar 2. Pertigaan Pemkot - Djati, Cimahi Sumber: Dokumentas Pribadi, 2019.

3) Pertigaan Sangkuriang, yang menjadi jalur yang dilalui siswa SMK TI Garuda, SMK Taruna Mandiri, dan SMK Sangkuriang Cimahi. 


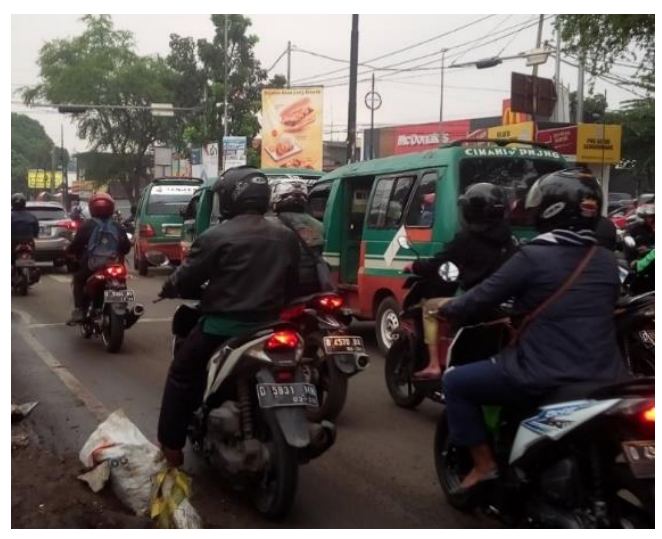

Gambar 3. Pertigaan Sangkuriang, Cimahi. Sumber: Dokumentas Pribadi, 2019

4) Jalan Gatot Soebroto Cimahi yang menjadi lokasi dari SMPN 6 Cimahi, SMAN 5 Cimahi, dan jalur untuk menuju ke SMPN 1 Cimahi. Maka dengan demikian anak sekolah di Kota Cimahi turut serta menjadi penyumbang angka kepadatan lalulintas di Kota Cimahi.

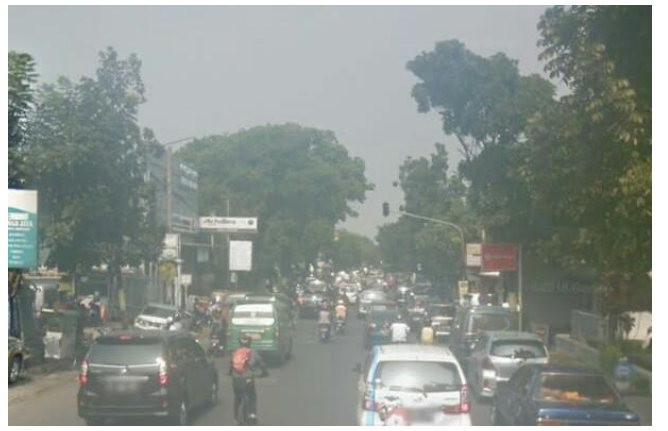

Gambar 4. Jalan Gatot Subroto, Cimahi. Sumber: Dokumentas Pribadi, 2019

\section{Penyelenggaraan Program Kampanye}

$\begin{array}{ccr}\begin{array}{c}\text { Satlantas } \\ \text { melaksanakan }\end{array} & \begin{array}{c}\text { Polres } \\ \text { program }\end{array} & \begin{array}{r}\text { Cimahi } \\ \text { kampanye }\end{array}\end{array}$ keselamatan lalu lintas sejak dini melalui transportasi sehat merakyat ini turun langsung ke semua sekolah-sekolah yang ada di Kota Cimahi, baik itu dari TK, SD, SMP, dan SMA, dengan tujuan memberikan edukasi, sosialisasi, dan wawasan mengenai keselamatan lalulintas dan transportasi sehat merakyat. Hal ini karena pihak Satlantas Polres Cimahi sudah melakukan diseminasi yang diprakarsai oleh Menteri Pendidikan, artinya pendidikan lalu lintas ini sudah masuk ke tingkat sekolah dan kemudian dijalankan oleh Dinas Pendidikan (Disdik) di daerah masing-masing.

Pihak Kementrian Pendidikan pun mengharuskan pendidikan lalu lintas ini masuk ke kurikulum sekolah, yaitu pada mata pelajaran Pendidikan Kewarganegaraan (PKn). Satlantas Polres Cimahi dengan Kanit Dikyasa IPDA Deden Indrajaya, S.H sebegai pembina, telah melakukan sosialisasi kepada sekolah-sekolah di Kota Cimahi. Namun ternyata belum seluruh sekolah-sekolah di Kota Cimahi yang menjalankan program tersebut.

\section{Konsep Program Kampanye}

Solusi untuk belum efektif dijalankannya program kampanye ini yaitu karena tidak adanya kegiatan yang bersifat kontinuitas dari program tersebut. Konsep program kampanye sebelumnya hanya berupa sekali kunjungan oleh pihak Satlantas Polres Cimahi ke satu sekolah lalu lanjut berindah ke sekolah lain. Melihat hal tersebut penulis akan membuat perubahan dalam kegiatan kampanye ini, yaitu membuat kegiatan kampanye ini dengan pendekatan melalui event tentang bersepeda, bersifat kontinuitas atau berkelanjutan selama beberapa bulan yang berfokus di sekolah yang sama, lalu lanjut berpindah ke sekolah lain.

Pelaksanaan kampanye pun harus dilakukan secara menarik, jika sebelumnya hanya berupa pihak Satlantas Polres Cimahi datang ke sekolah-sekolah hanya memberikan paparan, dan membagikan booklet tentang keselamatan lalu lintas dan rambu-rambu, nantinya kegiatannya akan berupa bersepeda bersama, talkshow, dan ada penampilan dari band bintang tamu, selain itu akan ada reward bagi siswa yang rajin dan aktif mengikuti kegiatan kampanye ini, dan selama pelaksanaan kegiatan ini tetap akan menyisipkan pendidikan tentang keselamatan lalu lintas oleh pihak Satlantas Polres Cimahi.

\section{Analisis SWOT}




\section{Strenght}

Strenght atau kekuatan yang dapat menjadi keunggulan program kampanye ini adalah:

1. Bersepeda dan berjalan kaki ke sekolah mampu menekan angka tingkat kepadatan lalulintas, khususnya yang disebabkan oleh pelajar

2. Bersepeda dan berjalan kaki ke sekolah dapat memaksimalkan kinerja otak, yang tentu sangat bermanfaat bagi pelajar untuk melaksanakan kegiatan belajar disekolah.

3. Bersepeda dan berjalan kaki ke sekolah dapat mengurangi polusi udara yang disebabkan oleh asap kendaraan bermotor.

\section{Weakness}

Weakness atau kelemahan yang dapat menjadi keunggulan program kampanye ini adalah:

1. Siswa yang jarak rumahnya terlalu jauh dengan sekolah tidak dapat ikut berpartisipasi

2. Tidak semua siswa sudah memiliki sepeda.

3. Tidak semua siswa bisa mengendarai sepeda.

\section{Opportunities}

Opportunities atau kesempatan yang dapat menjadi keunggulan program kampanye ini adalah:

1. Pendidikan keselamatan lalulintas dapat dilaksanakan dengan kegiatan yang menarik

2. Ketertarikan siswa terhadap bersepeda cukup antusias.

\section{Threat}

Threat atau ancaman yang dapat menjadi keunggulan program kampanye ini adalah:

1. Siswa lebih memilih menggunakan sepeda motor walaupun hal tersebut merupakan pelanggaran

2. Beberapa sekolah seolah-olah justru memfasilitasi siswanya yang menggunakan sepeda motor.

\section{Target Audience}

Berdasarkan data pada perancangan kampanye ini, target audience dibagi menjadi 2 kategori, yaitu:

\section{Target Khusus \\ Demografis}

Target primer dalam penelitian ini adalah siswa laki-laki dan perempuan yang ratarata berusia 15-17 tahun, SMAN 1 Cimahi, dengan status sebagai seorang pelajar. Sementara target sekunder dalam penelitian ini adalah pihak sekolah SMAN 1 Cimahi, dengan status sebagai staff, dan pengajar.

\section{Geografis}

Target primer dan sekunder dalam penelitian ini berlokasi di Sekolah Menengah Atas Negeri 1 Cimahi, Jl. Pacinan No.22 A, Cimahi, Cimahi Tengah, Kota Cimahi, Jawa Barat 40525.

\section{Psikografis}

Target primer dalam penelitian ini ditujukan pada siswa SMAN 1 Cimahi yang memiliki minat dan ketertarikan yang antusias dengan bersepeda dan berjalan kaki ke sekolah. Sementara target primer dalam penelitian ini ditujukan staff dan pengajar SMAN 1 Cimahi yang belum efektif melaksanakan kegiatan kampanye ini.

\section{Target Umum \\ Demografis}

Target primer dalam penelitian ini adalah anak laki-laki dan perempuan yang berusia sekitar 15-17 tahun, dengan status sebagai seorang pelajar. Sementara target sekunder dalam penelitian ini adalah staff dan pengajar SMA.

\section{Geografis}

Target primer dan sekunder dalam penelitian ini berlokasi di Sekolah Menengah Atas Kota Cimahi.

\section{Psikografis}

Target primer dalam penelitian ini ditujukan pada siswa SMA Kota Cimahi yang memiliki minat dan ketertarikan yang antusias dengan bersepeda dan berjalan kaki ke sekolah. Sementara target primer dalam penelitian ini ditujukan staff dan pengajar 
SMA Kota Cimahi yang belum efektif melaksanakan kegiatan kampanye ini.

\section{Hasil Data}

Hasil data yang penulis dapatkan melalui wawancara kepada Kanit Dikyasa Satlantas Polres Cimahi dan kuesioner yang telah diisi oleh siswa SMAN 1 Cimahi.

\section{Hasil Wawancara}

Wawancara dilakukan di Kantor Satlantas Polres Cimahi. Wawancara dilakukan oleh penulis dengan Bapak IPDA Deden Indrajaya, SH sebagai Kanit Dikyasa Satlantas Polres Cimahi pada 12 Desember 2018. Hasil wawancara tersebut digunakan untuk data-data pada penjelasan Bab I, Bab II, dan Bab III, diantaranya yaitu tentang program kampanye keselamatan lalu lintas sejak dini, fenomena di lapangan yang mendasari dijalankannya program tersebut, dan efektifitas program kampanye tersebut yang telah dijalankan.

\section{Hasil Kuesioner}

Berdasarkan hasil dari kuesioner yang sudah dibagikan dan diisi oleh 25 orang, dapat disimpulkan bahwa pada dasarnya program kampanye ini sudah penah ada namun belum efektif dijalankan, baik dari kegiatan dan media yang digunakan belum maksimal sehingga kurangnya minat dan ketertarikan dari para pelajarnya untuk menjalankan kegiatan kampanye keselamatan lalu lintas sejak dini melalui transportasi sehat merakyat ini.

\section{Konsep Perancangan}

Program Event Kampanye Berkelanjutan Program event kampanye berkelanjutan yaitu pelaksanaan kampanye melalui event yang dilakukan secara berkelanjutan, dari mulai pra kampanye, kampanye, dan pasca kampanye dengan mengaitkan kepada metode komunikasi AISAS. Menurut hasil survey kepada siswa Sekolah Menengan Atas (SMA) di Kota Cimahi, kampanye yang sudah dijalankan dirasa kurang efektif dikarenakan kampanye hanya dilakukan sekali pertemuan saja disatu sekolah, lalu berpindah ke sekolah lain. Strategi dan perangkat kampanye yang dilakukan pun belum maksimal, tidak adanya media untuk mempromosikan kampanye, publikasi kampanye yang belum maksimal, dan perangkat kampanye yang tidak tepat sasaran. Menyikapi permasalahan tersebut diperlukan strategi dan perangkat kampanye yang tepat dan bisa diterima oleh anak muda yaitu dengan mengadakan event bersepeda dan talkshow mengenai bersepeda yang dimeriahkan dengan penampilan band yang juga berpengaruh terhadap minat anak muda terhadap bersepeda. Pelaksanaan kampanye agar terstruktur dan efektif diperlukan timeline kampanye.

Kegiatan pra kampanye ini terdiri dari beberapa sesi, yaitu Attention, Interest, dan Search, hal-hal tersebut bersifat sebagai jembatan antara event dengan target. Attention adalah mencari atensi atau perhatian dari masyarakat, kegiatannya yaitu menyebarkan dan memasang poster disekolah dan sarana publik seperti billboard dengan menggunakan elemen visual yang kontras dan warna terang pada poster, namun hanya menampilkan angka dan masih menyamarkan elemen visual yang memiliki arti inti dari event tersebut, hal itu ditujukan agar masyarakat menjadi penasaran dan tertarik untuk mencari tahu. Interest berarti membuat masyarakat tertarik, kegiatannya yaitu menyebarkan dan memasang poster lanjutan (sequel) dari poster pertama yang disebarkan pada proses Attention. Poster lanjutan ini masih menggunakan warna yang terang namun sudah menampilkan sebagian dari elemen visual yang memiliki arti ini dari event ini yaitu sepeda, hal ini ditujukan agar masyarakat mulai tertarik karena sudah mulai bisa menebak-nebak dan kemdian mencari tahu informasi tentang poster tersebut. Search disini berarti mencari informasi, kegiatannya yaitu setelah masyarakat secara tidak langsung diarahkan oleh poster pertama dan poster kedua, kemudian semua informasi tentang event tersebut dimuat pada poster ketiga yang dipublikasikan di sosial media dan website event tersebut, juga dipublikasin di website resmi Polres Cimahi.

Strategi Komunikasi 
Strategi Komunikasi yang digunakan ialah menggunakan metode AISAS

Attention: Membuat poster bersekuel dengan warna kontras dan menampilkan hanya sebagian dari elemen visual utama

Interest: Membuat poster lanjutaan bersekuel dengan warna kontras dan menampilkan hanya sebagian dari elemen visual utama

Search : Sudah ada ketertarikan masyarakat dan para pelajar untuk mencari tahu tentang event "Bike for Good" di media cetak maupun media sosial

Action : $\quad$ Pelaksanaan event "Bike for Good" sebagai media untuk mengkampanyekan keselamatan lalu lintas sejak dini melalui transportasi sehat merakyat

Share : $\quad$ Setelah event berlangsung, kegiatan lanjutannya yaitu sosialisasi lanjutan dan pemilihan duta lalu lintas dengan terjun ke sekolah-sekolah secara berkelanjutan

Target audiensnya yaitu pelajar SMA di Kota Cimahi, dengan studi kasus di SMAN 1 Cimahi sebagai SMAN percontohan di Kota Cimahi.

\section{Strategi Pesan}

Strategi yang dilakukan dalam upaya mengkampanyekan kampanye keselamatan lalu lintas sejak dini melalui transportasi sehat merakyat ini pendekatannya melalui:

a. Pendekatan Melalui Event"Bike for Good",

Menggelar event bertajuk "Bike for Good" sebagai media yang menarik dan mudah masuk juga diterima oleh anak muda, dengan rangkaian acara yang menyenangkan menjadikan para peserta secara tidak langsung bisa mengkampanyekan kampanye ini, baik secara langsung mengikuti kegiatan ataupun membagikannya di sosial media.

b. Pendekatan Psikologis

Berdasarkan target audiens yang dituju, pelajar SMA cenderung lebih suka membagikan kegiatannya di sosial media, apalagi jika bertemu dengan idola atau public figure yang mereka ketahui, untuk itu pendekatan melalui event ini dengan cara mengundang bintang tamu Iqbaal Ramadhan, The Upstairs, dan The Changcuters, dengan demikian lebih mudah untuk menarik minat para pelajar untuk mengikuti kampanye ini karena adanya pendekatan psikologis antara mereka, bintang tamu, dan event "Bike for Good" tersebut.

c. Pendekatan Komunikasi

Komunikasi yang diberikan pada target audiens ini bersifat informatif tentang keselematan berlalu lintas dan persuasif untuk melaksanakannya.

\section{Strategi Kreatif}

Membuat booklet, event, maskot kampanye, poster kampanye, pengkat kegiatan event, dan stiker instagram story sebagai ide kreatif yang dijadikan media untuk mendorong target audiens mengikuti dan melaksanakan kampanye keselamatan lalu lintas sejak dini melalui transportasi sehat merakyat ini.

\section{Strategi Desain}

Layout

Layout adalah bagian dasar dari elemen desain, penyusunan objek-objek yang disusun dan disatukan dengan sedemikian rupa agar terlihat menarik. Layout yang digunakan pada media utama yaitu simple, tidak menampilkan banyak teks, dan lebih mengedepankan elemen ilustrasi. Ilustrasi vektor menjadi pilihan karena berdasarkan hasil riset lebih mudah diterima dan disukai oleh pelajar SMA.

Hal tersebut dikarenakan agar peserta lebih mudah memahami isi booklet dan tidak bosan jika lebih banyak menampilkan gambar - gambar. Menempatkan gambar disebelah kanan dan teks berlatar belakang balon kata bertujuan agar komposisinya seimbang, dan penggunaan latar belakang 
dengan visual seperti lahan terbuka hijau agar lebih berkesan segar dan leluasa.

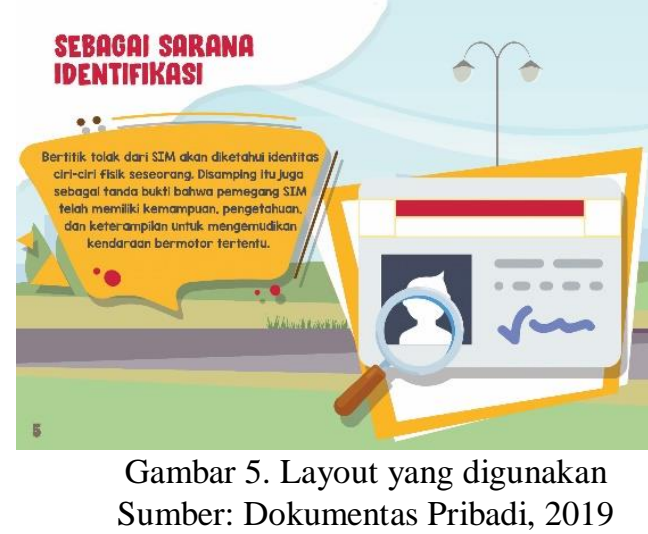

\section{Tipografi}

Tipografi adalah salah satu hal penting dalam desain, memiliki fungsi untuk penyampaian informasi dan komunikasi antara desain dengan audiens. Pemilihan tipografi pada perancangan ini yaitu menggunakan font yang simple dan cenderung lebih santai karena hasil dari quisioner yang dibagikan para pelajar lebih memilih font tersebut. Menggunakan font KG Blank Space Solid sebagai font utama, dan font Bloomer DEMO sebagai font kedua, agar lebih simple dan mudah diterima oleh target audiens para pelajar.

\section{BLOOMER DEMO}

\section{A B C D E F G H I JK L M N OP Q R S T U V WX Y Z 01236789}

Gambar 5. Tipografi yang digunakan Sumber: Dokumentas Pribadi, 2019

KG BLANK SPACE SOLID

\section{A B C DEF G H I JKL M NOPQRSTUVWXYZ abcdefghijk I m nopqrstuvw $x$ yz 01236789}

Gambar 6. Tipografi yang digunakan

\section{Sumber: Dokumentas Pribadi, 2019}

\section{Warna}

Warna merupakan suatu elemen penting dalam sebuah desain yang memiliki arti dan makna tersendiri. Warna dapat mewakili perasaan dan sisi emosional seseorang, baik secara langsung ataupun tidak langsung. Penggunaan warna dalam perancangan kampanye ini yaitu menggunakan palet warna playful color, yaitu warna-warna yang menggambarkan keceriaan, kesegaran dan optimisme tinggi. Warna-warna tersebut diambil dari logo yang ada pada logo Kota Cimahi dan warna turunannya. Hal tersebut dipilih berdasarkan atas hasil quisioner yang dibagikan kepada pelajar SMA di Kota Cimahi, warna-warna tersebut meliputi:

Tabel 4.6 Warna yang digunakan

\begin{tabular}{|c|c|}
\hline & Arti \\
\hline $\begin{array}{lr}\text { Prussion } & \text { Blue } \\
\text { (turunan } & \text { warna } \\
\text { biru) } & \end{array}$ & $\begin{array}{l}\text { Memberikan } \\
\text { konsistensi, } \\
\text { kepercayaan, } \\
\text { percaya diri. }\end{array}$ \\
\hline $\begin{array}{l}\text { Palm } \\
\text { (turunan } \\
\text { hijau) }\end{array}$ & $\begin{array}{ll}\text { Memberikan } & \text { arti } \\
\text { kehidupan, } & \\
\text { kesegaran, } & \text { dan } \\
\text { keseimbangan. } & \end{array}$ \\
\hline io (turunan & $\begin{array}{l}\text { Memberi kesan } \\
\text { kesejukan, } \\
\text { penyembuhan, dan } \\
\text { ketenangan }\end{array}$ \\
\hline $\begin{array}{l}\begin{array}{l}\text { Powder } \\
\text { (turunan } \\
\text { biru) }\end{array} \quad \text { warna } \\
\end{array}$ & $\begin{array}{l}\text { Memberikan } \\
\text { konsentrasi, } \\
\text { kesejukan, } \\
\text { komunikatif }\end{array}$ \\
\hline $\begin{array}{l}\text { (turunan } \\
\text { kuning) }\end{array}$ & $\begin{array}{l}\text { Memberikan kesan } \\
\text { berenergi, keceriaan, } \\
\text { dan tingkat } \\
\text { optimisme tinggi. }\end{array}$ \\
\hline $\begin{array}{l}\text { Amarnat } \\
\text { (turunan } \\
\text { merah) }\end{array}$ & $\begin{array}{l}\text { Memberikan kesan } \\
\text { bersemangat, enerjik, } \\
\text { dan penuh percaya } \\
\text { diri. }\end{array}$ \\
\hline $\begin{array}{l}\text { Tennessee Orange } \\
\text { (turunan warna } \\
\text { oranye) }\end{array}$ & \begin{tabular}{lr}
\multicolumn{2}{l}{ Merupakan } \\
pemaknaan dari jiwa \\
petualang, tingkat \\
kreativitas $\quad$ yang
\end{tabular} \\
\hline
\end{tabular}




\begin{tabular}{|l|l|}
\hline & $\begin{array}{l}\text { tinggi dan juga penuh } \\
\text { dengan keceriaan. }\end{array}$ \\
\hline
\end{tabular}

Sumber: Penulis, 2019

Palet warna playful color yang

digunakan dalam pembuatan booklet keselamatan lalu lintas bagi pengguna jalan yaitu:

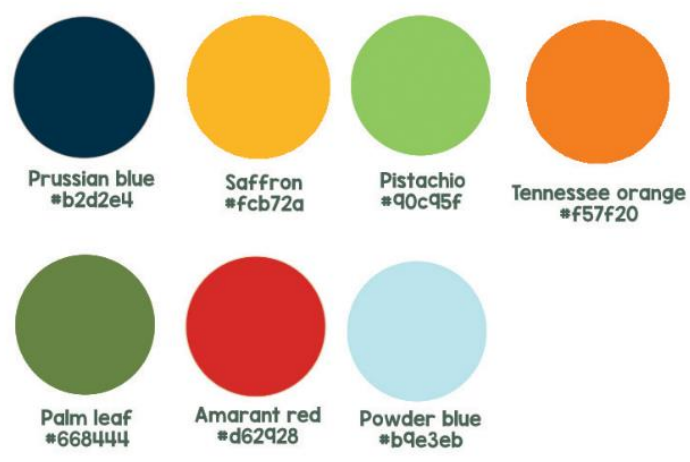

Gambar 7. Color mood

Sumber: Dokumentasi pribadi

\section{Strategi Media}

Pemilihan media adalah

berdasarkan dengan kebutuhan target audience. Adapun media yang digunakan terbagi menjadi dua, yaitu media utama dan media pendukung.

\section{Media Utama}

Media utama program kampanye ini yaitu booklet, booklet adalah buku berukuran kecil setengah kuarto dan tidak lebih dari 30 lembar bolak balik yang berisikan tulisan dan gambar. Pemilihan booklet sendiri adalah permintaan dari Satlantas Polres Cimahi karena media kampanye sebelumnya pun menggunakan booklet. Selain itu, ada beberapa kelebihan dari booklet menjadi pertimbangan diantaranya yaitu dapat digunakan sebagai media belajar mandiri, disini dimaksudkan agar nantinya para pelajar yang menjadi peserta bisa mempelajari tentang panduan keselamatan berkendara secara mandiri setelah event ini selesai, selanjutnya yaitu booklet memiliki kelebihan dalam segi teknis yaitu mudah dibuat, diperbanyak, disesuaikan, dan juga mudah diarahkan pada segmen tertentu.

Kelebihan booklet tersebut juga dibarengi dengan kekurangannya yaitu sulit menampilkan gerak dihalaman, contohnya saat menjelaskan 12 gerakan pengaturan lalu lintas, dan juga kekurangannya yaitu pesan dan informasi yang terlalu banyak dapat mrngurangi minat membaca media tersebut. Ukuran dari booklet yang dibuat yaitu ukuran A5 atau $21 \mathrm{~cm} \times 14,8 \mathrm{~cm}$, ukuran tersebut mengacu pada ukuran standar booklet dan ukuran yang juga digunakan pada booklet yang dibuat oleh Satlantas Polres Cimahi.

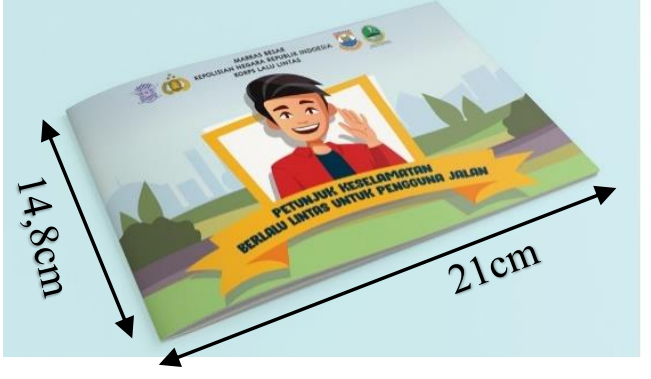

Gambar 8. Ukuran Booklet

Sumber: Dokumentasi pribadi

\section{Cover Booklet}

cover booklet ini menampilkan maskot kampanye yaitu Bhara sedang tersenyum dan melambaikan tangan, hal ini menunjukan bahwa kampanye ini dijalankan penuh keceriaan dan kehangatan.

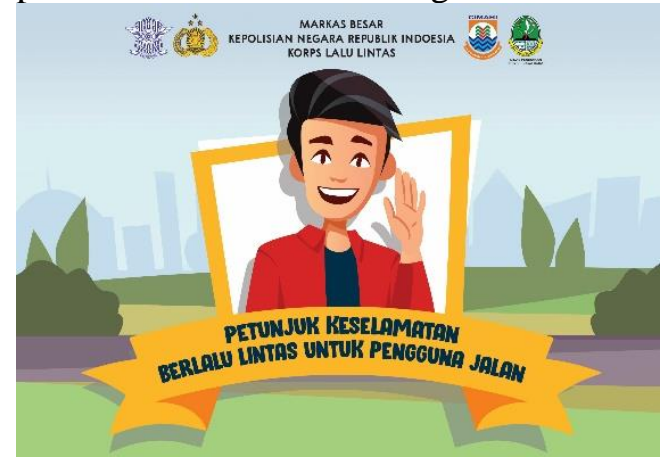

Gambar 9. Cover Booklet

Sumber: Dokumentasi pribadi

Hukum Penerbitan Surat Izin Mengemudi (SIM)

Halaman berisikan portrait dari maskot kampanye Bhara yang menjelaskan tentang hukum penerbitan SIM. 


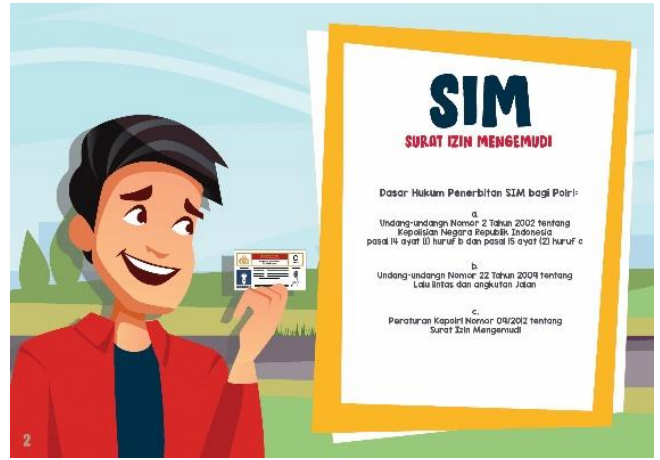

Gambar 10. Hukum Penerbitan SIM Sumber: Dokumentasi pribadi

Fungsi dan Peranan Surat Izin Mengemudi (SIM)

Halaman berisikan ilustasi SIM serta fungsi dan pernanannya.

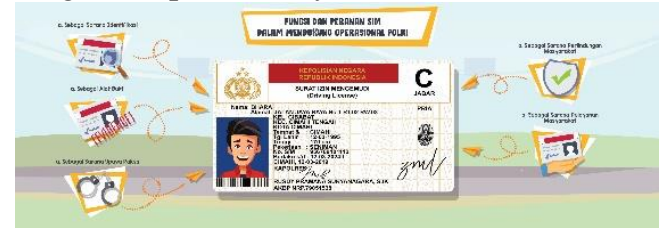

Gambar 11. Fungsi dan Peranan SIM

Sumber: Dokumentasi pribadi

Penjelasan Fungsi dan Peranan Surat Izin Mengemudi (SIM)

Halaman berisikan penjelasan yang lebih rinci tentang fungsi dan pernanan SIM.

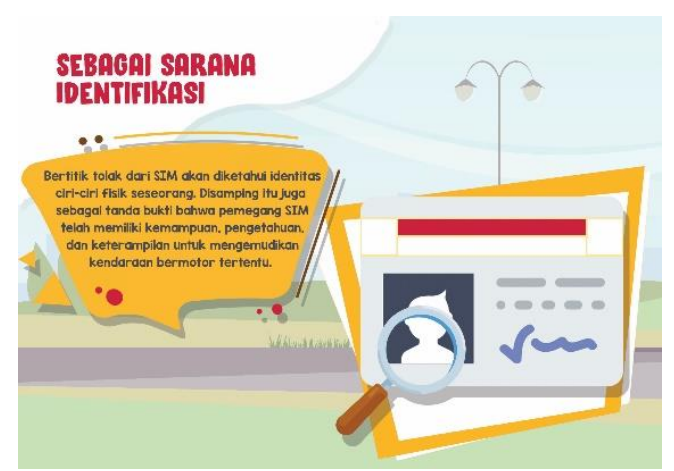

Gambar 12. Penjelasan Fungsi dan Peranan SIM Sumber: Dokumentasi pribadi

\section{Klasifikasi Surat Izin Mengemudi (SIM)}

Halaman berisikan klasifikasi dari SIM, yaitu meliputi persyaratan dan peruntukannya.

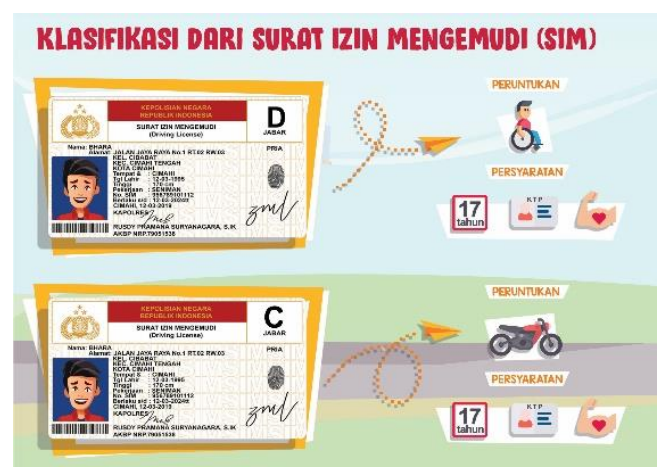

Gambar 13. Klasifikasi SIM

Sumber: Dokumentasi pribadi

\section{Pakaian Layak Untuk Berkendara}

Halaman berisikan petunjuk tentang bagaimana contoh pakaian yang layak untuk berkendara

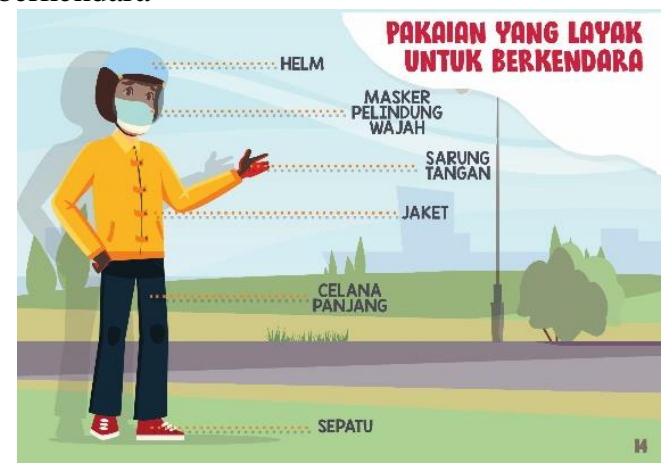

Gambar 14. Pakaian layak untuk berkendara Sumber: Dokumentasi pribadi

Penjelasan Pakaian Layak Untuk Berkendara

Halaman berisikan penjelasan lebih spesifik dari setiap item bagian dari pakaian yang layak untuk berkendara

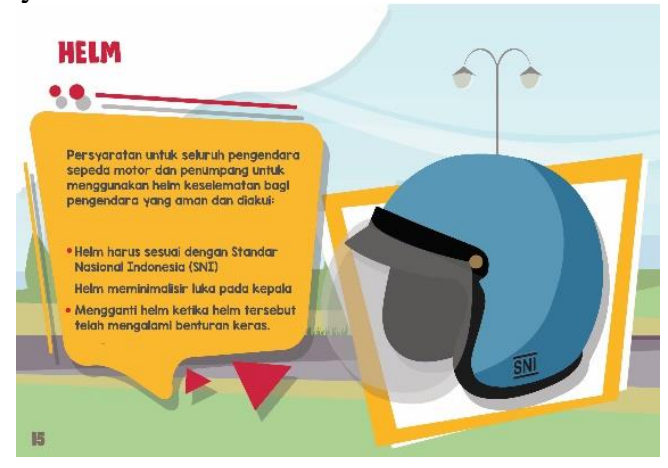

Gambar 15. Penjelasan item dari pakaian layak untuk berkendara

Sumber: Dokumentasi pribadi 


\section{Pakaian Layak Untuk Bersepeda}

Halaman berisikan petunjuk tentang bagaimana contoh pakaian yang layak untuk bersepeda

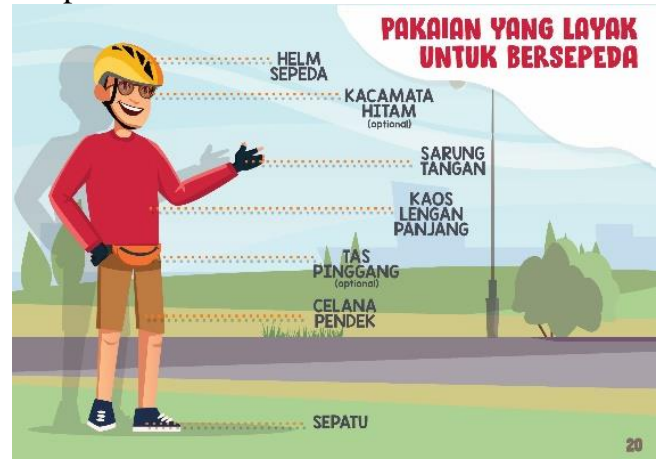

Gambar 16. Pakaian layak untuk bersepeda Sumber: Dokumentasi pribadi

\section{Penjelasan Pakaian Layak Untuk Bersepeda}

Halaman berisikan penjelasan lebih spesifik dari setiap item bagian dari pakaian yang layak untuk berkendara

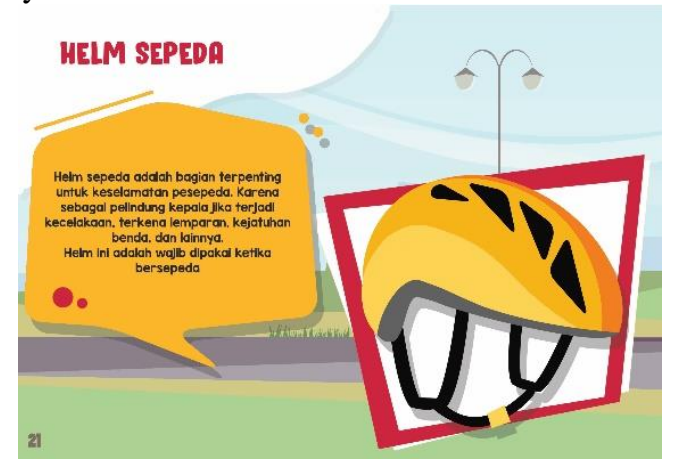

Gambar 17. Penjelasan item dari pakaian layak untuk bersepeda

Sumber: Dokumentasi pribadi

\section{Bagian-bagian Sepeda}

Halaman berisikan ilustasi sepeda dengan petunjuk setiap bagian-bagiannya.

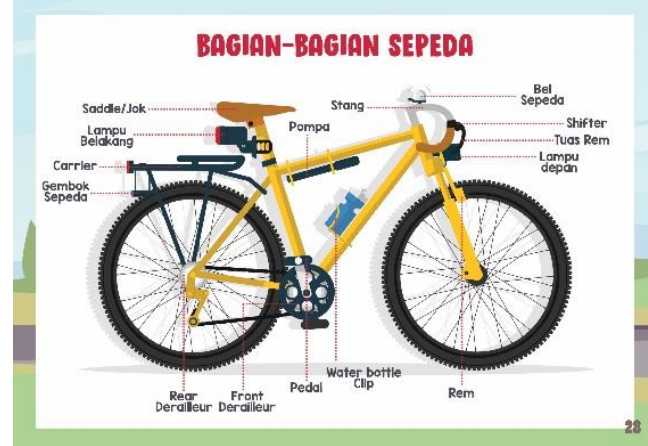

Gambar 18. Bagian-bagian sepeda
Sumber: Dokumentasi pribadi

\section{Hal Wajib Saat Bersepeda}

Halaman berisikan item yang wajib digunakan saat bersepeda

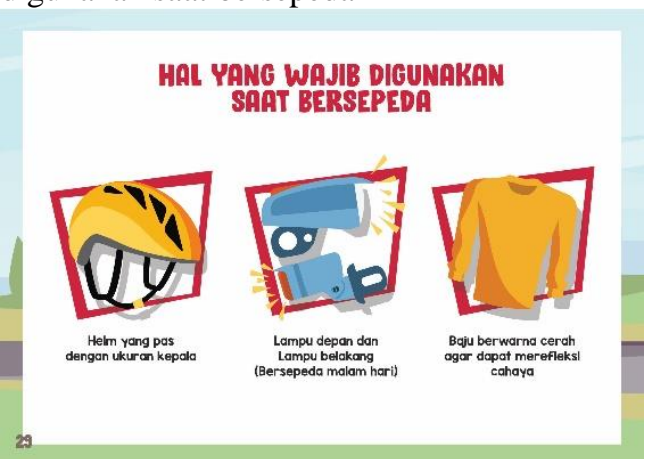

Gambar 19. Hal wajib saat bersepeda

Sumber: Dokumentasi pribadi

\section{Periksa Kondisi Sepeda}

Halaman berisikan petunjuk pemeriksaan kondisi sepeda sebelum digunakan.

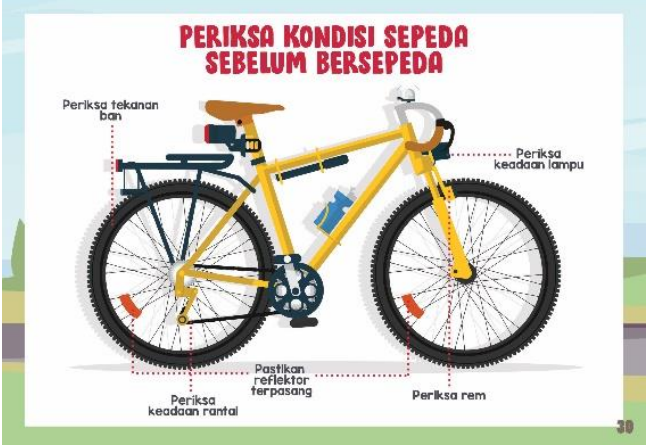

Gambar 20. Periksa kondisi sepeda Sumber: Dokumentasi pribadi

\section{Etika Bersepeda}

Halaman berisikan etika saat bersepeda, khususnya saat bersepeda di jalan raya

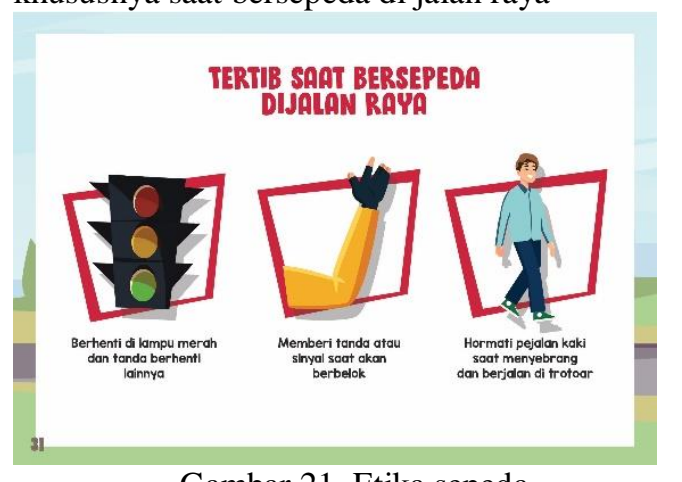

Gambar 21. Etika sepeda

Sumber: Dokumentasi pribadi

\section{Rambu Lalu lintas}


Halaman berisikan rambu-rambu lalu lintas, salah satunya yaitu rambu peringatan

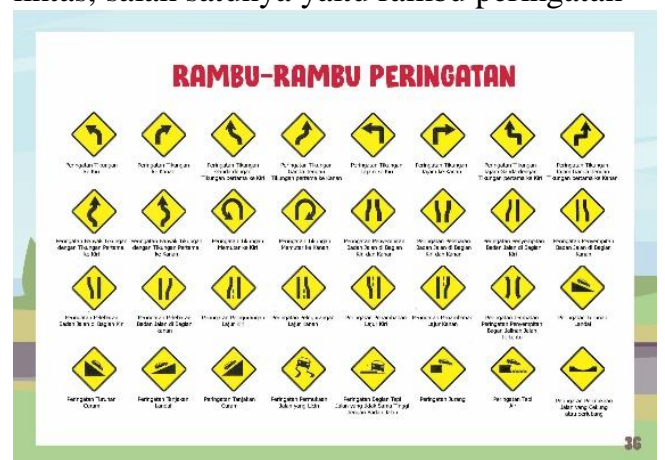

Gambar 22. Rambu Peringatan

Sumber: Dokumentasi pribadi

\section{Gerakan Pengaturan Lalu Lintas}

Halaman berisikan 12 gerakan pengaturan lalu lintas yang dilakukan oleh petugas.

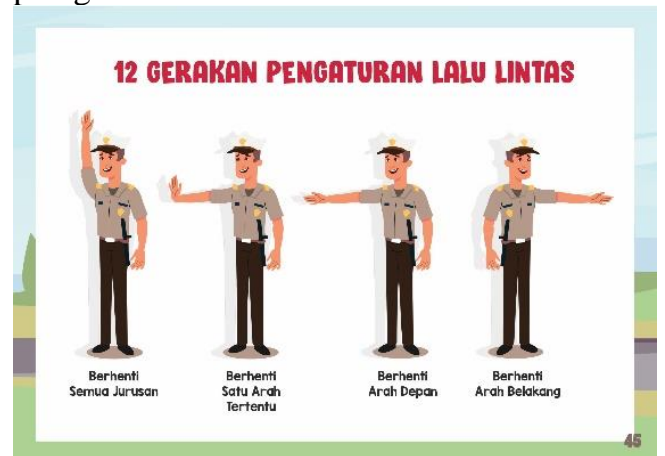

Gambar 23. 12 Gerakan pengaturan lalu lintas Sumber: Dokumentasi pribadi

\section{Media Pendukung \\ Poster}

Poster sebagai media pendukung memiliki peran yang sangat penting yaitu sebagai media visual yang bertujuan untuk publikasi, menyampaikan pesan kampanye ini sehingga mampu mempengaruhi dan memotivasi orang agar mengikuti dan turut serta dalam mengkampanyekan kampanye tersebut. Poster dibagi menjadi beberapa sesi berdasarkan waktu publikasinya, yaitu poster pertama, poster lanjutan, dan poster jawaban dari poster pertama dan lanjutan.

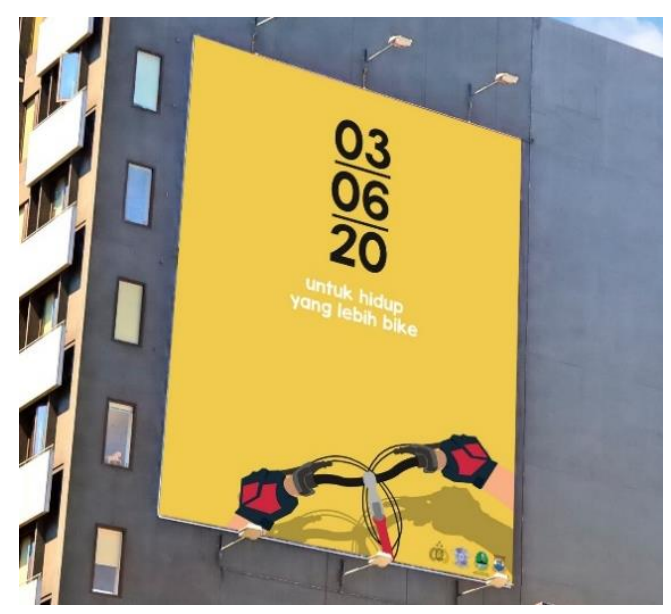

Gambar 24. Poster Pertama

Sumber: Dokumentasi pribadi

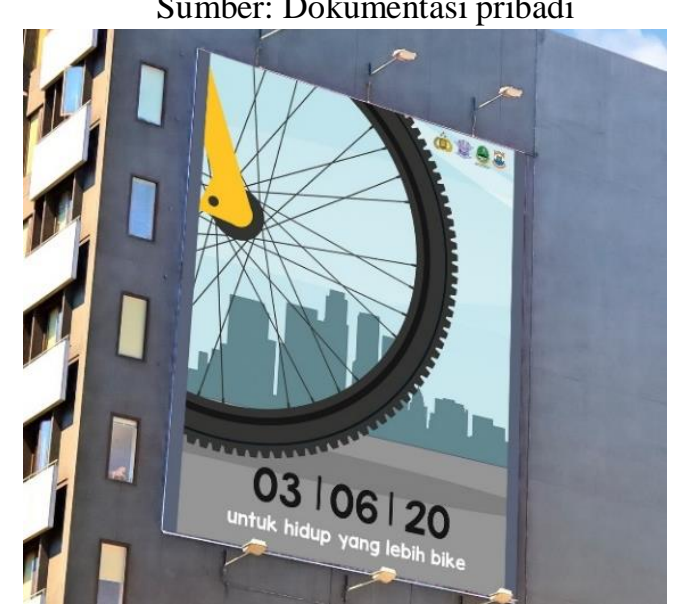

Gambar 25. Poster lanjutan

Sumber: Dokumentasi pribadi

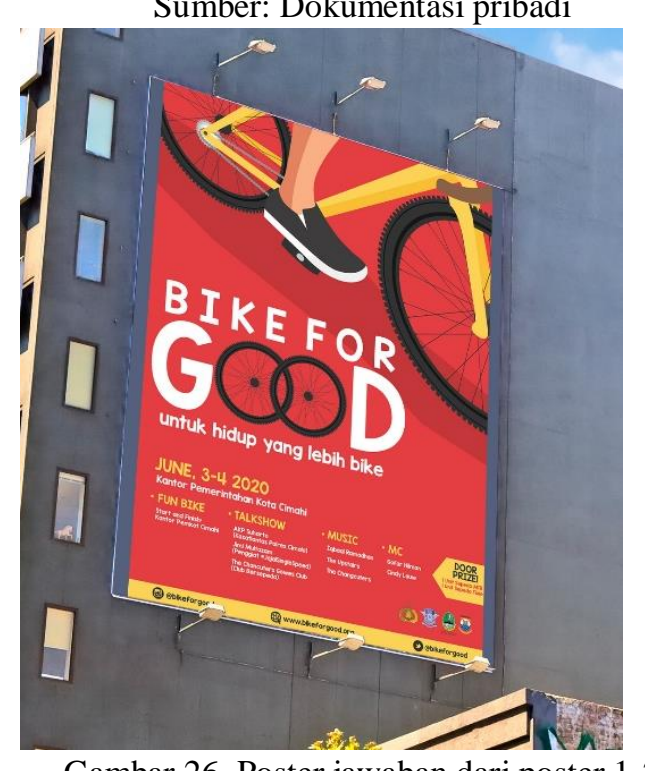

Gambar 26. Poster jawaban dari poster 1-2 Sumber: Dokumentasi pribadi 


\section{Maskot}

Maskot dibuat untuk memudahkan dalam melakukan pendekatan kepada target audiens yaitu para pelajar. Maskot kampanye ini yaitu Bhara, berasal dari kata Bhayangkara yang merupakan istilah untuk dunia Kepolisian Indonesia. Bhara adalah siswa SMA dan berusia 17 tahun. Maskot ini adalah hasil dari riset melalui pembagian kuisioner dengan target pelajar SMA.

Secara karakter Bhara memiliki karakter yang pintar, rajin, bersemangat, dan taat terhadap aturan lalu lintas. Secara fisik Bhara memiliki postur tubuh yang tinggi dan bugar, hal itu karena Bhara gemar berolahraga, yaitu bersepeda.

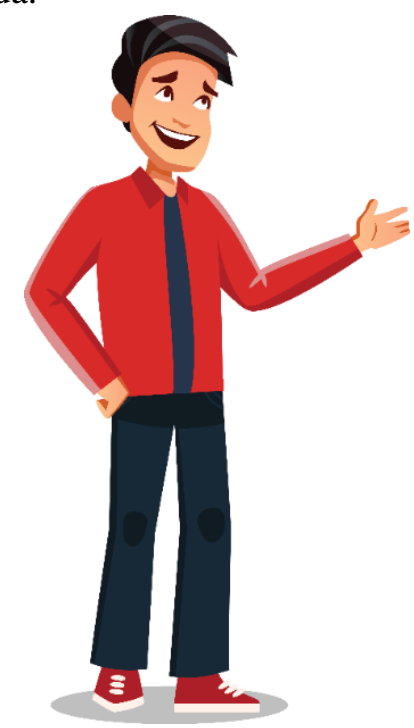

\section{Instagram Feed Layout}

Instagram adalah platform digital atau aplikasi untuk berbagi foto di sosial media, Instagram Feed Layout ini yaitu layout kolom postingan foto pada profil akun Instagram yang di desain menjadi menarik jika dilhat secara keseluruhan ataupun setiap postingan. Konten dari setiap postingannya pun berisi tentang publikasi dan penyampaian segala informasi tentang kampanye dan event Bike for Good ini, namun yang membedakan dengan website, instagram lebih fleksibel dan lebih mudah diarahkan, selain itu juga, instagram sangat mudah untuk

\section{Gambar 27. Maskot Bhara}

Sumber: Dokumentasi pribadi

\section{Website Banner}

Website banner memliki peran sebagai media publikasi secara digital dengan jangkauan yang lebih luas dan lebih resmi. Website banner menampilkan segala informasi yang berhubungan dengan kampanye dan event Bike for Good tersebut

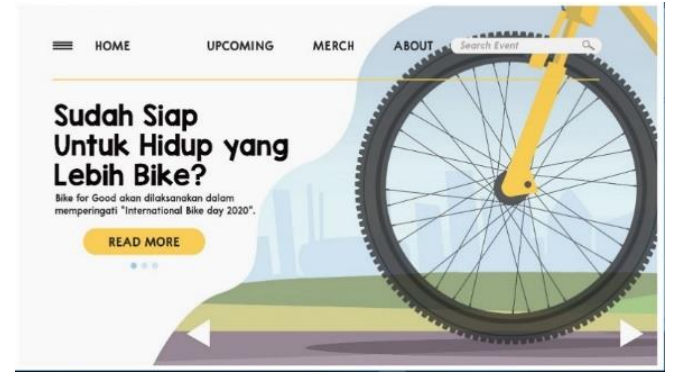

Gambar 28. Website Banner

Sumber: Dokumentasi pribadi membagikan informasi kepada pengguna instagram yang lain.
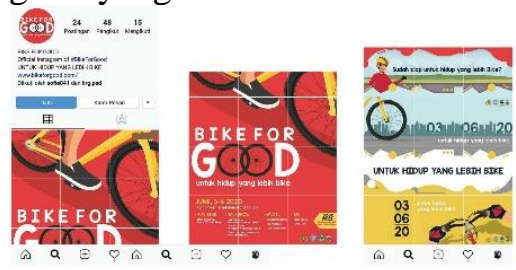

Gambar 29. Tampilan Instagram Feed Sumber: Dokumentasi pribadi

\section{Instagram Story Sticker}

Selain berbagi foto dan video dikolom postingan, instagram juga memiliki fitur instagram story, yaitu setiap pengguna bisa membagikan gambar, foto, dan video selama kurang lebih 15 detik 
dengan menambahkan teks, emoji, dan sticker GIF, pada kolom sticker GIF pengguna bisa menggunakan sticker GIF edisi khusus event Bike for Good ini dengan mengetikan kata kunci "bikeforgood" dikolom pencarian sticker. Proses publikasi dan penyebaran informasi terjadi ketika pengguna instagram membagikan storynya yang terdapat sticker edisi khusus event Bike for Good dilihat oleh orang lain dikolom Instagram story dimasing-masing pengguna Instagram.

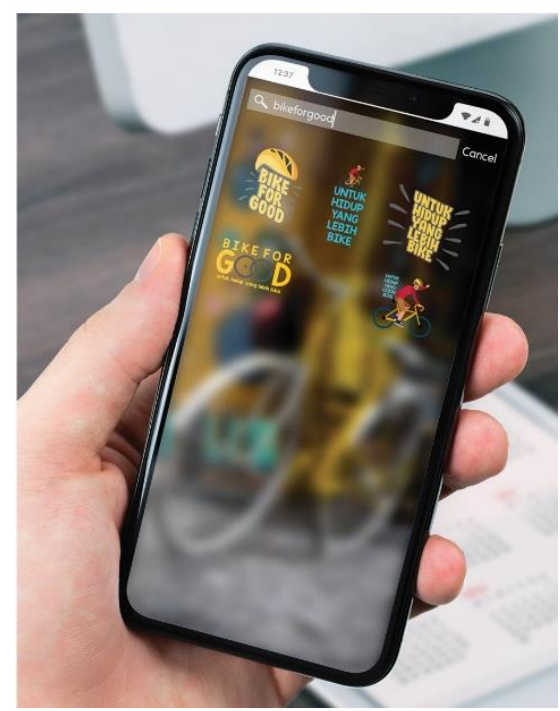

Gambar 30. Tampilan Instagram Story Sticker Sumber: Dokumentasi pribadi

\section{T-Shirt}

T-shirt event Bike for Good ini dibagikan dihari pertama saat peserta melakukan registrasi, T-shirt ini bisa digunakan saat mengikuti kegiatan Fun Bike dan dibawa pulang sebagai merchandise dari event Bike for Good, hal tersebut ditujukan agar ketika event berlangsung orang-orang dijalan dapat mengetahui adanya event tersebut dengan mudah, dan juga dengan T-shirt tersebut dibawa pulang sebagai merchandise, para peserta bisa menggunakannya ketika bersepeda atau kegiatan lainnya setelah event ini berlangsung, hal tersebut secara tidak langsung sesuai dengan visi kampanye ini yang bersifat berkelanjutan.

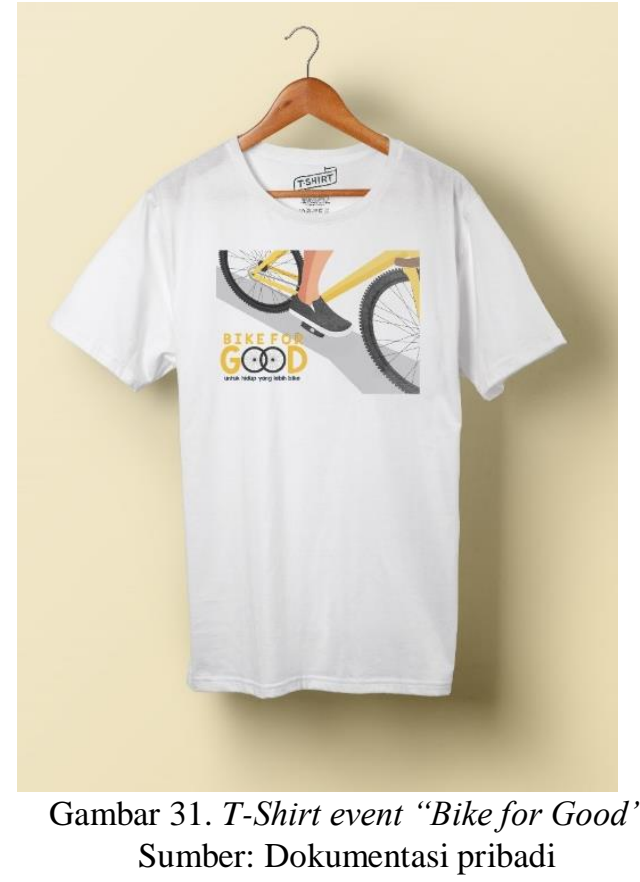

Perangkat Kegiatan

Kegiatan kampanye melalui event Bike for Good ini tentu membutuhkan panitia yang tidak sedikit, untuk itu agar mempermudah panitia dalam mengkoordinir acara tersebut setiap panitia dan peserta harus menggunakan kartu panitia dan kartu peserta, selain itu agar panitia dan para peserta bersemangat dalam mengikuti kampanye-kampanye selanjutnya, diakhir acara peserta dan panitia akan diberikan sertifikat sebagai apresiasi telah mau mengikuti event Bike for Good sebagai media untuk mengkampanyekan keselamatan lalu lintas sejak dini melalui transportasi sehat merakyat. 


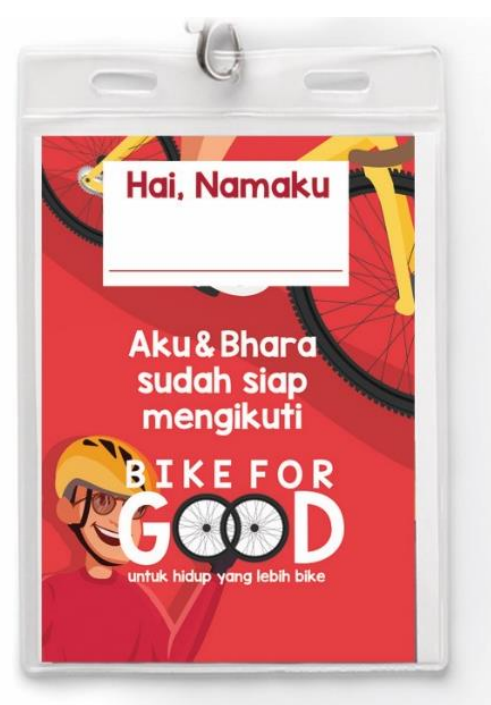

Gambar 32. Kartu Peserta

Sumber: Dokumentasi pribadi

Kartu peserta dipakai ketika peserta mengikuti event "Bike For Good" dan ketika selesai peserta diberikan sertifikat telah berpartisipasi dalam kegiatan ini.

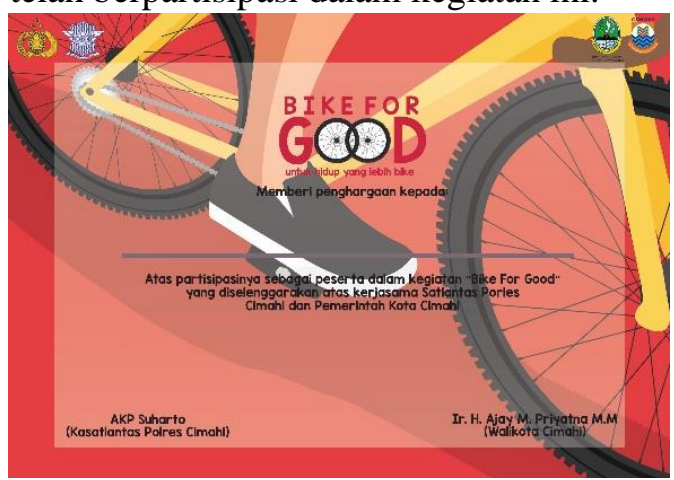

Gambar 33. Sertifikat Peserta

Sumber: Dokumentasi pribadi

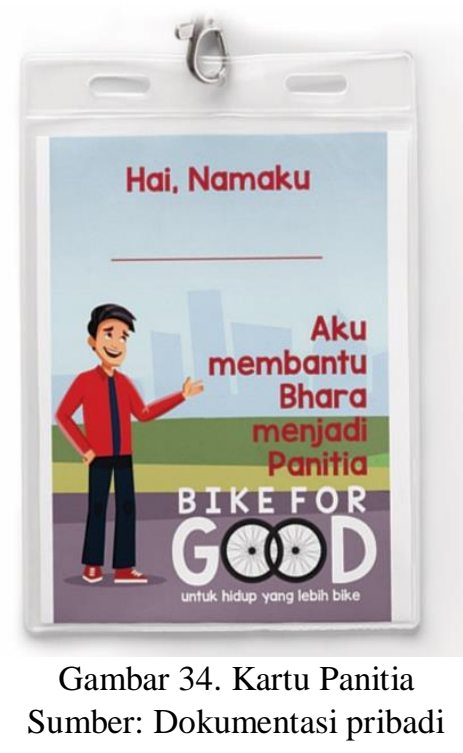

Peserta menggunakan kartu peserta saat event berlangsung, begitu juga dengan panitia dan setelah event ini selesai panitia juga mendapatkan sertifikat keikutsertaan sebagai panitia event "Bike For Good"

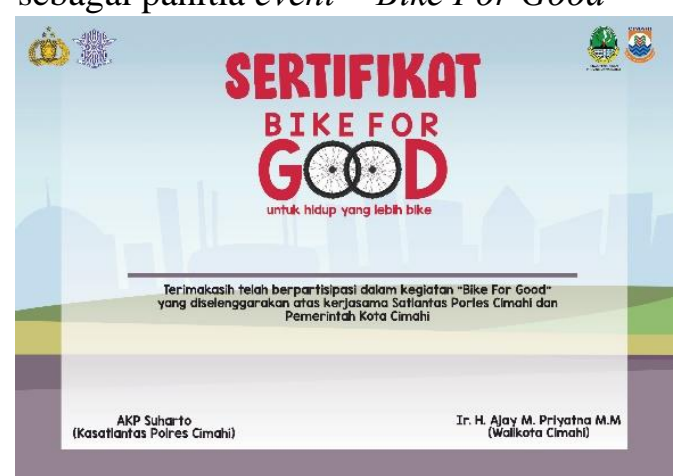

Gambar 35. Sertifikat Panitia

Sumber: Dokumentasi pribadi

\section{KESIMPULAN}

Program kampanye keselematan lalu lintas sejak dini melalui transportasi sehat merakyat ini adalah program nasional yang diamanatkan dalam Pasal 203 UU no 22 Tahun 2009 tentang lalu lintas dan angkutan jalan. Program kampanye ini ditujukan untuk mereduksi angka tingkat kecelekaan dan kepadatan lalu lintas yang disebabkan oleh pelajar SMA yang menggunakan sepeda motor ke sekolah. Namun adapun masalah yang membuat kampanye tersebut belum efektif dijalankan, diantaranya yaitu: 
1. Kampanye tersebut belum dijalankan secara maksimal, baik secara media maupun secara teknis pelaksanaan

2. Masih banyak pelajar yang jarak antara rumah dan sekolahnya dekat maupun jauh, lebih memilih menggunakan sepeda motor ke sekolah, daripada bersepeda atau Saran menggunakan angkuta umum.

Saran dari perancangan infografis interaktif tanggap gempa bagi anak-anak usia 8 sampai 12 tahun di SDN 3 Lembang yaitu:

1. Saran Akademis. Dengan adanya infografis interaktif tanggap gempa yang dapat diakses melalui website ini semoga mahasiswa desain komunikasi visual dapat lebih kreatif dalam memilih media untuk berkarya, agar permasalahan yang ada dapat diselesaikan dengan efektif.

2. Saran Praktis. Dengan adanya infografis interaktif tanggap gempa diharapkan para siswa-siswi di SDN 3 Lembang dapat mengerti dan tanggap akan bencana gempa bumi.

\section{REFERENSI}

Antar, Venus. 2004. Manajemen Kampanye. Bandung : Simbiosa Rekatama Media.

Gustaning, Guni. 2014. Pengembangan media booklet menggambar macammacam celana pada kompetensi dasar menggambar celana SMAN 1 Jenar. Yogyakarta: Univeeritas Negeri Yogyakarta

Heru. Desain Komunikasi Visual Pengertian, Ruang Lingkup, dan Jenisnya.

Melaluihttps://pakarkomunikasi.com/k $<$ https://pakarkomunikasi.com/pengerti

\section{Rujukan Website:}

Sugiyama, Kotaro., dan Andree, Tim. 2011. The Dentsu Way. New York : McGrew-Hill. an-komunikasi-menurut-para-ahli>.

Diakses pada 19 April 2019

omunikasi-visual>. Diakses pada 19 April 2019

Ivony. 35 Pengertian Komunikasi

Menurut Para Ahli. Melalui

Kamaludin, Hilman. 2018. Kadisdik Kota Cimahi Minta Polisi Tindak Tegas Pelajar yang Membawa Motor. Melalui <http://jabar.tribunnews.com/2018/07/ 23/kadisdik-kota-cimahi-minta-polisitindak-tegas-pelajar-yang-membawamotor>. Diakses pada 9 November 2018

Kamaludin, Hilman. 2018. Pengendara Motor Usia Remaja Penyumbang Kecelakaan Terbanyak di Wilkum Polres Cimahi. Melalui http://jabar.tribunnews.com/2018/07/23 /pengendara-motor-usia-remajapenyumbang-kecelakaan-terbanyak-diwilkum-polres-cimahi Diakses pada 9 November 2018

Kurniawan, Aris 2019. Pengertian Tipografi menurut Para Ahli beserta Contohnya Lengkap. Melalui $<$ https://www.gurupendidikan.co.id/pe ngertian-tipografi-menurut-para-ahlibeserta-contohnya-lengkap/>. Diakses pada 22 April 2019

Kurniawan, Aris. 2019. Pengertian Ilustrasi menurut Para Ahli beserta Sejarah, Fungsi, dan Tujuannya.

Melalui <https://www.gurupendidikan.co.id/ilu strasi/>. Diakses pada 22/ April 2019

Kusrianto, Adi. 2009. Pengantar Desain Komunikasi Visual: Creating Color Schemes.

Ruang Guru. 2018. 13 Pengertian Definisi Desain Menurut Para Ahli Terlengkap. Melalui $<$ https://www.ruangguru.co.id/pen gertian-desain-menurut-paraahli/> Diakses pada 19 April 2019

Yuwono, Syahreza. 2016. Perancangan media kampanye bike to school untuk pelajar sma di kota bandung "studi kasus di sman 13 kota bandung” 
Bandung: Universitas Informatika dan Bisnis Indonesia 